\title{
Pengaruh Gaya Kepemimpinan, Motivasi dan Stres Kerja Terhadap Kinerja Pegawai Badan Pengelolaan Keuangan dan Aset Daerah Kabupaten Jember
}

\author{
(The Effect of Leadership Style, Work Motivation and Stress on Employee \\ Performance of the Regional Financial and Asset Management \\ Agency of Jember Regency)
}

\author{
Aldy Purnama Indrianto*, Mochamad Syaharudin, Budi Nurhardjo \\ Jurusan Manajemen, Fakultas Ekonomi dan Bisnis, Universitas Jember (UNEJ) \\ Jln. Kalimantan 37, Jember 68121 \\ E-mail: aldy366@gmail.com
}

\begin{abstract}
Abstrak
Penelitian ini bertujuan untuk mengetahui pengaruh gaya kepemimpinan, motivasi dan stres kerja terhadap kinerja pegawai. Badan Pengelolaan Keuangan dan Aset Daerah Kabupaten Jember. Populasi dalam penelitian ini adalah pegawai Badan Pengelolaan Keuangan dan Aset Daerah Kabupaten Jember yang berjumlah 73 orang. Tehnik pengambilan sampel menggunakan metode sensus atau sampel jenuh merupakan suatu teknik penentuan sampel bila semua anggota populasi digunakan sebagai sampel. Jenis data menggunakan data kualitatatif melalui berbagai macam teknik pengumpulan data serta data kuantitatif dimana data yang berbentuk angka atau bilangan. Sumber data yang digunakan menggunakan data primer data yang dikumpulkan melalui pihak pertama, biasanya dapat melalui wawancara, kuesioner dan observasi yang bertujuan untuk menunjang penelitian ini dan data sekunder dimana di peroleh dari jurnal, artikel dan internet yang mendukukung. Metode analisis data menggunakan statistik deskriptif, uji instrumen, uji asumsi klasik, dan pengujian hipotesis yang terdiri dari metode analisis regresi linier berganda serta uji t. Hasil penelitian menunjukan bahwa gaya kepemimpinan, motivasi dan stres kerja berpengaruh terhadap kinerja Pegawai Badan Pengelolaan Keuangan dan Aset Daerah Kabupaten Jember. Kata Kunci: Gaya Kepemimpinan, Motivasi, Stres Kerja Dan Kinerja.
\end{abstract}

Kata Kunci: Gaya Kepemimpinan, Motivasi, Stres Kerja Dan Kinerja.

\section{Abstract}

This study aims to determine the effect of leadership style, motivation and work stress on the performance of employees of the Regional Financial and Asset Management Agency in Jember Regency. The population in this study were 73 employees of the Regional Financial and Asset Management Agency of Kabupaten Jember. The sampling technique using the census or saturated sample method is a sampling technique if all members of the population are used as samples. The type of data uses qualitative data through various types of data collection techniques and quantitative data where data in the form of numbers or numbers. Sources of data used using primary data data collected through the first party, usually can be through interviews, questionnaires and observations that aim to support this research and secondary data which is obtained from journals, articles and internet support. The method of data analysis uses descriptive statistics, instrument test, classic assumption test, and hypothesis testing consisting of multiple linear regression analysis methods and t test. The results showed that leadership style, motivation and work stress had an effect on the performance of the Regional Financial and Asset Management Agency Employees in Jember Regency.

Keywords: Leadership Style, Motivation, Job Stress and Performance.

\section{Pendahuluan}

Pemerintah daerah dalam melaksanakan kegiatan pemerintahan umum yang menjadi kewenangan presiden dimana pelaksanaannya dilimpahkan kepada gubernur dan bupati / wali kota dan dibiayai oleh APBN. Peraturan ini menjadikan pemerintah daerah memperoleh kewenangan untuk mengelola keuangan daerahnya secara mandiri agar dapat melayani berbagai kepentingan masyarakat.

APBD sebagai dokumen daerah yang memuat kebijakan anggaran perlu mendapatkan perhatian yang serius, hal ini dikarenakan APBD memuat fungsi distribusi anggaran. Hal yang perlu dipertimbangkan dalam penyusunan
APBD adalah mempertimbangkan aspek kemampuan dari daerah serta keberpihakan kepada masyarakat banyak. Prinsip transparansi, akuntabilitas, partisipasi dan kesejahteraan merupakan syarat wajib terwujudnya APBD yang pro rakyat, diawali dari proses perencanaan hingga pelaksanaan, monitoring dan evaluasi, sehingga prinsip tersebut terlaksana.

Kepala Satuan Kerja Pengelola Keuangan Daerah selaku Pejabat Pengelola Keuangan Daerah memiliki tugas menyusun laporan keuangan pemerintah daerah yang kemudian disampaikan kepada gubernur / bupati / walikota guna memenuhi pertanggungjawaban pelaksanaan APBD sebagaimana tercantum dalam

\footnotetext{
* Corresponding author
} 
Undang undang RI nomor 1 Tahun 2004 pasal 56 ayat 1. Laporan keuangan tersebut selanjutnya akan diperiksa dan diberi opini oleh Badan Pemeriksa Keuangan (Opini BPK) terkait kewajaran informasi keuangan yang tersaji dalam laporan

Keuangan yang didasarkan pada empat kriteria, yakni apakah sesuai dengan standar akuntansi pemerintahan, kepatuhan terhadap peraturan perundangundangan, kecukupan pengungkapan (adequate disclosures), dan efektivitas sistem pengendalian intern. Opini BPK terbagi menjadi empat jenis yang dapat diberikan oleh pemeriksa menurut undang-undang nomor 15 tahun 2004, pertama wajar tanpa pengecualian atau unqualified opinion (WTP), opini wajar tanpa pengecualian merupakan opini audit yang akan diterbitkan apabila laporan keuangan dianggap memberikan informasi yang bebas dari salah saji material. Jika laporan keuangan perusahaan / pemerintah memperoleh opini jenis ini, artinya auditor meyakini berdasarkan buktibukti audit yang dikumpulkan, perusahaan / pemerintah dianggap telah melaksanakan prinsip akuntansi yang berlaku secara umum dengan baik, dan kalaupun terdapat kesalahan, kesalahannya dianggap tidak material dan tidak berpengaruh signifikan terhadap pengambilan keputusan.

Opini kedua wajar dengan pengecualian atau qualified opinion (WDP). Opini wajar dengan pengecualian merupakan opini audit yang akan diterbitkan apabila sebagian besar informasi dalam laporan keuangan bebas dari salah saji material. Opini ketiga tidak wajar atau adversed opinion (TW) yang merupakan opini audit yang akan diterbitkan apabila laporan keuangan mengandung salah saji material, atau dengan kata lain laporan keuangan tidak mencerminkan keadaan yang sebenarnya. Opini keempat tidak menyatakan pendapat atau disclaimer of opinion (TMP). Opini tidak menyatakan pendapat bagi sebagian akuntan dianggap bukanlah sebuah opini, dengan asumsi apabila auditor menolak memberikan pendapat artinya tidak ada opini yang diberikan. Opini jenis ini diberikan apabila auditor tidak dapat meyakini apakah laporan keuangan wajar atau tidak.

Menurut Sucipto (2007) menyatakan bahwa definisi kinerja keuangan daerah adalah tingkat pencapaian dari suatu hasil kerja di bidang keuangan daerah yang meliputi penerimaan dan belanja daerah dengan menggunakan sistem keuangan yang ditetapkan melalui suatu kebijakan atau ketentuan perundang-undangan selama satu periode anggaran. Sumber daya manusia yang baik dan mempunyai kinerja yang tinggi sangat diperlukan untuk mencapai keberhasilan suatu instansi pemerintah dengan memperhatikan faktorfaktor yang mempengaruhinya.

Variabel yang mempengaruhi kinerja pegawai pada suatu organisasi salah satunya yaitu gaya kepemimpinan, seperti pendapat dari Zainal \& Mulyadi (2010:42) menyatakan gaya kepemimpinan adalah sekumpulan ciri yang digunakan pimpinan untuk memengaruhi bawahannya agar tujuan organisasi tercapai atau dapat pula dikatakan gaya kepemimpinan merupakan pola perilaku dan strategi yang disukai dan sering diterapkan oleh seorang pimpinan. Dalam hal ini pengaruh yang disengaja dijalankan oleh seseorang terhadap orang lain untuk menstruktur aktivitas - aktivitas serta hubungan hubungan di dalam sebuah kelompok atau organisasi.

Selain gaya kepemimpinan, motivasi juga merupakan salah satu variabel yang mempengaruhi kinerja pegawai pada suatu organisasi. Menurut Hasibuan (2016), motivasi merupakan daya penggerak yang diberikan guna menciptakan kegairahan kerja seseorang, sehingga mereka mau bekerja terintegrasi dan bekerja sama dengan segala upayanya untuk mencapai kepuasan. Keberadaan motivasi merupakan suatu komponen yang sangat penting dalam hubungannya dengan pergawai. Apabila dikelola dengan baik motivasi akan membantu perusahaan / organisasi dalam mencapai tujuannya, karena pegawai tergerak agar mau bekerja secara maksimal guna mencapai keinginan dari pegawai tersebut. Sebaliknya apabila motivasi tidak dikelola dengan baik, bisa jadi akan mengurangi kinerja pegawai tersebut dan tujuan perusahaan / organisasi tidak dapat tercapai. menyatakan motivasi kerja sebagai kesediaan untuk melaksanakan upaya tinggi untuk mencapai tujuan-tujuan keorganisasian yang dikondisikan oleh kemampuan untuk memenuhi kebutuhan individual tertentu. Apabila dilihat dari sisi lain, jika pegawai merasa puas dengan apa yang diperoleh dari motivasi yang diberikan perusahaan maka akan bekerja dengan maksimal, tugasnya akan diselesaikan dengan penuh semangat sehingga akan meberikan hasil yang baik. Untuk itu, organisasi memberikan motivasi balas jasa dan kenaikan pangkat untuk mempengaruhi kinerja pegawai yang baik.

Suatu organisasi yang memiliki kinerja baik, tentu memiliki sumber daya manusia yang baik pula di dalamnya. Para pegawai juga dituntut untuk bekerja semaksimal mungkin, secepat mungkin dalam menyelesaikan pekerjaannya. Hal ini dapat membuat masalah pada kondisi pegawai yang akan menimbulkan stres kerja. Menurut Zainal \& Mulyadi (2010:308), stres kerja adalah suatu kondisi ketegangan yang disebabkan perbedaan karakter individu yang dapat berakibat pada penurunan kinerja pegawai. Dalam mengelola dan mengendalikan stres kerja perlu sekali untuk mengetahui terlebih dahulu pemicu terjadinya stres kerja (stressors), kemudian mengelola dan mengendalikan pemicu dari stres kerja tersebut menjadikan solusi bagi organisasi untuk meredam besarnya stres di tempat kerja. Semakin kecil tingkat stres kerja, maka semakin meningkat tingkat kinerja pegawai pada suatu organisasi. Dari hasil observasi dan wawancara pegawai Badan Pengelolaan Keuangan dan Aset Daerah Kabupaten Jember, pada saat tertentu seperti akhir bulan dan tahun pegawai mengalami kejenuhan yang disebabkan beban pekerjaan bertambah dan berbeda dari waktu biasanya. Kejenuhan pada pekerjaan ini dapat menjadi pemicu tejadinya stres dan akan terjadi konflik pada diri mereka sendiri, pada kondisi tersebut pegawai tidak mampu memaksimalkan kinerjnya di dalam suatu organisasi.

Rumusan masalah dalam artikel ini apakah gaya kepemimpinan, motivasi dan stres kerja berpengaruh terhadap kinerja Pegawai Badan Pengelolaan Keuangan dan Aset Daerah Kabupaten Jember. Artikel ini bertujuan 
untuk mengetahui dan menganalisis apakah gaya kepemimpinan, motivasi dan stres kerja berpengaruh terhadap kinerja Pegawai Badan Pengelolaan Keuangan dan Aset Daerah Kabupaten Jember.

\section{Metode}

\section{Rancangan Penelitian}

Penelitian ini menggunakan jenis penelitian explanatory research, karena penelitian ini menjelaskan hubungan kausal antara variabel-variabel melalui pengujian hipotesis atau penelitian penjelasan.

\section{Populasi dan Sampel}

Populasi pada penelitian ini adalah pegawai Badan Pengelolaan Keuangan dan Aset Daerah Kabupaten Jember. Metode pengambilan sampel dalam penelitian ini dilakukan dengan metode sensus atau sampel jenuh merupakan suatu teknik penentuan sampel bila semua anggota populasi digunakan sebagai sampel yang berjumlah 73 orang.

\section{Jenis dan Sumber Data}

Penelitian ini menggunakan penelitian kuantitatif. Hal ini dikarenakan data yang diperoleh nantinya merupakan data berupa angka. Sumber data yang digunakan pada penelitian ini yaitu data primer dan data sekunder Data primer dalam penelitian ini diperoleh dari hasil penyebaran kuesioner sedangkan data sekunder dalam penelitian ini diperoleh dari sumber-sumber yang relevan dengan topik penelitian.

\section{Metode Analisis Data}

Penelitian ini menggunakan metode analisis analisis regresi linier berganda.

\section{Hasil Dan Pembahasan}

\section{Hasil}

\section{Karakteristik Responden}

Berikut ini disajikan statistik deskriptif untuk masingmasing variabel yang digunakan dalam penelitian ini dan data tentang karakteristik responden. Data yang digunakan dalam penelitian ini meliputi data-data sebagai berikut: Umur, Jenis Kelamin, Pendikikan Terkahir dan Masa Bekerja. Data deskriptif responden sebagai berikut

Tabel 1. Karakteristik Responden Berdasarkan Umur

\begin{tabular}{lll}
\hline Umur & Jumlah & Presentase (\%) \\
\hline 25 - 30 tahun & 12 & 17,9 \\
$31-35$ tahun & 26 & 38,8 \\
36 - 40 tahun & 21 & 31,3 \\
$>40$ tahun & 8 & 11,9 \\
\hline Total & 67 & 100 \\
\hline
\end{tabular}

Sumber: data primer diolah, 2019

Berdasarkan tabel 1 menunjukkan bahwa usia responden memiliki usia 25 - 30 tahun sebanyak 12 orang (17,9\%), usia 31 - 35 tahun sebanyak 26 orang $(38,8 \%)$, Usia $36-$
40 tahun sebanyak 21 orang (31,3\%), Dan Usia $>40$ tahun sebanyak 8 orang $(11,9 \%)$.

Tabel 2. Karakteristik Responden Berdasarkan Jenis Kelamin

\begin{tabular}{lll}
\hline Usia & Jumlah & Presentase (\%) \\
\hline Laki - Laki & 56 & 83.6 \\
Perempuan & 11 & 16.4 \\
\hline Total & 67 & 100 \\
\hline
\end{tabular}

Sumber: data primer diolah, 2019

Berdasarkan tabel 2 menunjukkan bahwa responden yang berjenis kelamin perempuan yaitu sebanyak 11 orang $(16,4 \%)$. Sedangkan yang berjenis kelamin lakilaki sebesar 56 orang $(83,6 \%)$.

Tabel 3. Karakteristik Responden Berdasarkan Pendidikan

\begin{tabular}{lll}
\hline Pendidikan & Jumlah & Presentase (\%) \\
\hline DIPLOMA & 2 & 2,9 \\
S1 & 47 & 70,2 \\
S2 & 18 & 26,9 \\
\hline Total & 67 & 100
\end{tabular}

Sumber: data primer diolah, 2019

Berdasarkan tabel 3 menunjukkan bahwa jumlah responden yang berpendidikan terakhir DIPLOMA yaitu sebanyak 2 orang $(2,9 \%)$, responden yang berpendidikan terakhir S1 yaitu sebanyak 47 orang $(70,2 \%)$, dan responden yang berpendidikan terakhir S2 yaitu sebanyak 18 orang $(26,9 \%)$

Tabel 4. Karakteristik Responden Berdasarkan Masa Kerja

\begin{tabular}{cll}
\hline Lama Bekerja & Jumlah & Presentase $(\%)$ \\
\hline$<1$ tahun & 1 & 14 \\
$1-3$ tahun & 9 & 13.4 \\
$4-6$ tahun & 33 & 49.2 \\
$>6$ tahun & 24 & 35.8 \\
\hline Total & 67 & 100
\end{tabular}

Sumber: data primer diolah, 2019

Berdasarkan tabel 4 menunjukkan bahwa jumlah responden dengan Lama Bekerja $<1$ tahun sebanyak 1 orang $(13,4 \%), 1-3$ tahun sebanyak 9 orang $(13,4 \%), 4-$ 6 tahun sebanyak 33 orang $(49,2 \%)$ dan $>6$ tahun sebanyak 24 orang $(35,8 \%)$.

\section{Uji Validitas}

Korelasi antara masing-masing indikator variabel Gaya Kepemimpinan (X1), Motivasi (X2), Stres Kerja (X3) dan Kinerja Pegawai (Y) menunjukkan hasil yang signifikan dengan nilai Rhasil $>$ Rtabel dan Sig $<0,05$. Hal ini dapat disimpulkan bahwa semua item pertanyaan variabel Gaya 
Kepemimpinan (X1), Motivasi (X2), Stres Kerja (X3) dan Kinerja Pegawai (Y) dinyatakan valid.

\section{Uji Reliabilitas}

Tabel 5. Hasil Uji Reliabiitas

\begin{tabular}{lccl}
\hline \multicolumn{1}{c}{ Variabel } & Nilai & Alpha & Ket \\
\hline $\begin{array}{l}\text { Gaya Kepemimpinan } \\
\text { (X1) }\end{array}$ & 0,760 & 0,60 & Reliabel \\
Motivasi (X2) & 0,742 & 0,60 & Reliabel \\
Stres Kerja (X3) & 0,799 & 0,60 & Reliabel \\
Kinerja (Y) & 0,763 & 0,60 & Reliabel \\
\hline
\end{tabular}

Sumber: output uji reliabilitas 2019

Pada tabel 5 dapat disimpulkan bahwa semua variabel yang digunakan dalam penelitian ini adalah reliabel karena memiliki nilai Cronbach Alpha yang lebih besar dari 0,60 .

\section{Analisis Regresi Linier Berganda}

Analisis regresi linier berganda umumnya digunakan untuk menguji pengaruh dua atau lebih variabel bebas terhadap variabel terikat Rekapitulasi hasil analisis regresi adalah sebagai berikut :

Tabel 6. Analisis Regresi Linier Berganda

\begin{tabular}{cccc}
\hline $\begin{array}{c}\text { Variabel } \\
\text { Regresi }\end{array}$ & Koefisien & Sig & Keterangan \\
\hline Konstan & 4,323 & - & - \\
Gaya & 0,426 & 0,000 & Signifikan \\
$\begin{array}{c}\text { Kepemimpina } \\
\text { n (X1) }\end{array}$ & & & \\
$\begin{array}{c}\text { Motivasi (X2) } \\
\text { Stres Kerja } \\
(X 3)\end{array}$ & 0,109 & 0,011 & Signifikan \\
\hline
\end{tabular}

Sumber: Data diolah, 2019

Berdasarkan Tabel 6 di atas model diagram analisis jalur beserta koefisiennya dapat ditunjukkan pada gambar berikut :

$$
\mathrm{Y}=4,323+0,426 \mathrm{X} 1 \mathrm{Y}+0,109 \mathrm{X} 2 \mathrm{Y}+0,128 \mathrm{X} 3 \mathrm{Y}+\mathrm{e}
$$

a Nilai Konstanta

Dari persamaan diatas didapatkan nilai konstanta sebesar

4,323 yang berarti bahwa jika nilai dari variabel independen Gaya Kepemimpinan (X1), Motivasi (X2), Stres Kerja (X3) sama dengan nol, maka Kinerja Pegawai (Y) adalah sebesar konstanta 4,323.

\section{b. Gaya Kepemimpinan (X1)}

Nilai koefisien dari variabel Gaya Kepemimpinan adalah bernilai positif 0,426 yang berarti bahwa setiap kenaikan satu satuan variabel tersebut, akan meningkatkan

Kinerja Pegawai sebesar 0,426 c. Motivasi (X2)

Nilai koefisien dari variabel Motivasi adalah bernilai positif 0,109 yang berarti bahwa setiap kenaikan satu satuan variabel tersebut, akan meningkatkan Kinerja Pegawai sebesar 0,426 .

\section{d. Stres Kerja (X3)}

Nilai koefisien dari variabel Stres Kerja adalah bernilai positif 0,128 yang berarti bahwa setiap kenaikan satu satuan variabel tersebut, akan meningkatkan Kinerja Pegawai sebesar 0,128 .

\section{Uji Asumsi Klasik}

\section{Uji Normalitas}

Setelah dilakukan uji normalitas dapat diketahui bahwa hasil dari uji normalitas, data terdistribusi dengan normal, karena data memiliki nilai probabilitas atau signifikansi yakni lebih besar dari 0,05

\section{Uji Multikolinieritas}

Tabel 7. Hasil Uji Multikolinieritas

\begin{tabular}{|c|c|c|}
\hline Variabel & VIF & Keterangan \\
\hline $\mathrm{X} 1$ & 1,007 & $\begin{array}{l}\text { Tidak Terjadi } \\
\text { Multikolinieritas }\end{array}$ \\
\hline $\mathrm{X} 2$ & 1,007 & $\begin{array}{l}\text { Tidak Terjadi } \\
\text { Multikolinieritas }\end{array}$ \\
\hline $\mathrm{X} 2$ & 1,006 & $\begin{array}{l}\text { Tidak Terjadi } \\
\text { Multikolinieritas }\end{array}$ \\
\hline
\end{tabular}

Sumber: output uji reliabilitas 2019

Berdasarkan tabel 7 bahwa model tidak terjadi multikolinieritas. Hal tersebut ditandai dengan nilai VIF dari masing-masing variabel $<10$.

\section{Uji Heterokedastisitas}

Setelah dilakukan uji heterokadekstisitas dengan menggunakan scatter plot yaitu titik-titik yang dihasilkan pada gambar tersebut menyebar dan berbentuk tidak beraturan sehingga dapat dikatakan tidak terjadi heteroskesdastisitas.

\section{Hasil Uji t}

Tabel 8. Hasil Uji t

\begin{tabular}{lll}
\hline Variabel & Sig & Keterangan \\
\hline Hipotesis 1 & 0,000 & Signifikan \\
Hipotesis 2 & 0,011 & Signifikan \\
Hipotesis 3 & 0,018 & Signifikan \\
\hline
\end{tabular}

Sumber: output uji t 2019

Berdasarkan tabel 8 dapat diketahui besar dari pengaruh masing-masing variabel

\section{Hipotesis 1}

Berdasarkan Tabel diatas dapat dilihat bahwa Tingkat signifikansi $(\alpha)$ dari variabel Gaya Kepemimpinan (X1) adalah $0,000<0,05$. Hal ini berarti Gaya Kepemimpinan berpengaruh signifikan terhadap Kinerja Pegawai (H1 diterima). 


\section{Hipotesis 2}

Berdasarkan Tabel diatas dapat dilihat bahwa Tingkat signifikansi $(\alpha)$ dari variabel Motivasi (X2) adalah 0,011 < 0,05 . Hal ini berarti Motivasi berpengaruh signifikan terhadap Kinerja Pegawai (H2 diterima).

\section{Hipotesis 3}

Berdasarkan Tabel diatas dapat dilihat bahwa Tingkat signifikansi $(\alpha)$ dari variabel Stres Kerja (X3) adalah $0,018<0,05$. Hal ini berarti Stres Kerja (X3) berpengaruh signifikan terhadap Kinerja Pegawai (H3 diterima)

\section{Pembahasan}

\section{Gaya Kepemimpinan Berpengaruh Terhadap Kinerja Pegawai}

Hasil analisis regresi berganda pada Uji t terhadap hipotesis pertama (H1) menunjukkan bahwa Gaya Kepemimpinan berpengaruh terhadap Kinerja Pegawai dengan melihat taraf signifikansinya yaitu sebesar 0,000. Hubungan yang ditunjukkan oleh koefisien regresi adalah positif artinya semakin baik Gaya Kepemimpinan maka Kinerja Pegawai akan semakin meningkat (H1 diterima). Hasil tersebut diperkuat oleh jawaban responden terkait dengan variabel Gaya Kepemimpinan dan Kinerja Pegawai dengan rata-rata memberikan jawaban setuju. Hasil penelitian mengindikasikan bahwa semakin baik Gaya Kepemimpinan maka semakin tinggi persepsi terhadap Kinerja Pegawai.

Menurut Kartono (2008:34) gaya kepemimpinan sebagai bentuk sifat, kebiasaan, tempramen, watak dan kepribadian yang membedakan seorang pemimpin dalam berinteraksi dengan orang lain. Hasibuan (2016:167) menyatakan gaya kepemimpinan merupakan suatu cara pemimpin untuk memengaruhi pegawai suatu organisasi, hal ini bertujuan agar pegawai mau bekerja keras dan bersama mencapai tujuan dari organisasi. Menurut beberapa pendapat sebelumnya, dapat disimpulkan bahwa gaya kepemimpinan merupakan suatu cara pemimpin yang terefleksi dalam tindakan dan perkataan guna memengaruhi pegawai agar mau bekerja lebih keras guna mencapai tujuan organisasi.

Hasil penelitian ini sejalan dengan penelitian sebelumnya yang dilakukan Usmany et al. (2016) yang menyatakan bahwa terdapat pengaruh yang signifikan dari Gaya Kepemimpinan terhadap kinerja Pegawai. Jadi dapat disimpulkan Gaya Kepemimpinan berpengaruh terhadap kinerja Pegawai Badan Pengelolaan Keuangan dan Aset Daerah Kabupaten Jember di Jember.

\section{Motivasi Berpengaruh Terhadap Kinerja Pegawai}

Hasil analisis regresi berganda pada Uji t terhadap hipotesis kedua (H2) menunjukkan bahwa Motivasi berpengaruh terhadap Kinerja Pegawai dengan melihat taraf signifikansinya yaitu sebesar 0,011 . Hubungan yang ditunjukkan oleh koefisien regresi adalah positif artinya semakin baik Motivasi maka Kinerja Pegawai akan semakin meningkat (H1 diterima).

Hasil tersebut diperkuat oleh jawaban responden terkait dengan variabel Motivasi dan Kinerja Pegawai dengan ratarata memberikan jawaban setuju. Hasil penelitian mengindikasikan bahwa semakin baik Motivasi maka semakin tinggi persepsi terhadap Kinerja Pegawai.

Menurut Robescu \& Iancu (2016:49) motivasi adalah segala kekuatan pendorong baik internal mupun eksternal yang membuat individu melakukan suatu kegiatan beriorientasi pada pencapaian tujuan tertentu. Organisasi mengharapkan pegawai untuk menggunakan pengetahuan, tenaga, keterampilan, dan sebagian waktunya untuk bekerja secara maksimal pada suatu organisasi, di lain pihak pegawai juga mengharapkan menerima suatu imbalan tertentu. Artinya, organisasi dapat merangsang motivasi pegawai untuk bekerja lebih maksimal melalui pemberian nilai, hadiah, dan juga penghargaan. Jika anggota organisasi tidak merasa memiliki motivasi untuk bekerja, dampaknya bagi perusahaan / organisasi akan sangat bersifat negatif dan dapat mengganggu jalannya kegiatan dalam perusahaan / organisasi.

Hasil penelitian ini sejalan dengan penelitian sebelumnya yang dilakukan Lusri \& Siagian (2017) yang menyatakan bahwa terdapat pengaruh yang signifikan dari Motivasi terhadap kinerja Pegawai. Jadi dapat disimpulkan Motivasi berpengaruh terhadap kinerja Pegawai Badan Pengelolaan Keuangan dan Aset Daerah Kabupaten Jember di Jember.

\section{Stress Kerja Berpengaruh Terhadap Kinerja Pegawai}

Hasil analisis regresi berganda pada Uji t terhadap hipotesis ketiga (H3) menunjukkan bahwa Stress Kerja berpengaruh terhadap Kinerja Pegawai dengan melihat taraf signifikansinya yaitu sebesar 0,018 . Hubungan yang ditunjukkan oleh koefisien regresi adalah positif artinya semakin baik Stress Kerja maka Kinerja Pegawai akan semakin meningkat (H1 diterima).

Hasil tersebut diperkuat oleh jawaban responden terkait dengan variabel Stress Kerja dan Kinerja Pegawai dengan rata-rata memberikan jawaban setuju. Hasil penelitian mengindikasikan bahwa semakin baik Stress Kerja maka semakin tinggi persepsi terhadap Kinerja Pegawai.

Stres kerja sebagai suatu kondisi ketegangan yang mempengaruhi proses berpikir, emosi, dan kondisi seseorang, hasilnya stres yang terlalu berlebihan dapat mengancam kemampuan seseorang untuk menghadapi lingkungan dan pada akhirnya akan mengganggu pelaksanaan tugastugasnya. akibatnya dapat menghambat pelaksanaan tugas-tugasnya. Stres yang tidak diatasi dengan baik biasanya berakibat pada ketidakmampuan seseorang berinteraksi secara positif dengan lingkungannya, baik dalam arti lingkungan pekerjaan maupun di luarnya. Artinya, pegawai yang bersangkutan akan menghadapi berbagai gejala negatif yang pada akhirnya berpengaruh terhadap kinerjanya.

Hasil penelitian ini sejalan dengan penelitian sebelumnya yang dilakukan Lusri \& Siagian (2017) yang menyatakan bahwa terdapat pengaruh yang signifikan dari Stress Kerja terhadap kinerja Pegawai. Jadi dapat disimpulkan Stress Kerja berpengaruh terhadap kinerja Pegawai Badan Pengelolaan Keuangan dan Aset Daerah Kabupaten Jember di Jember. 


\section{Simpulan}

Berdasarkan hasil analisis dan pembahasan yang telah peneliti jelaskan maka dapat disimpulkan sebagai berikut :

1. Gaya Kepemimpinan berpengaruh positif terhadap Kinerja Pegawai Badan Pengelolaan Keuangan dan Aset Daerah Kabupaten Jember di Jember.

2. Motivasi berpengaruh positif terhadap Kinerja Pegawai Badan Pengelolaan Keuangan dan Aset Daerah Kabupaten Jember di Jember.

3. Stress Kerja berpengaruh positif terhadap Kinerja Pegawai Badan Pengelolaan Keuangan dan Aset Daerah Kabupaten Jember di Jember.

\section{Ucapan Terima Kasih}

Peneliti mengucapkan terima kasih pada Pegawai Badan Pengelolaan Keuangan dan Aset Daerah Kabupaten Jember di Jember. atas partisipasinya menjadi responden penelitian dan terima kasih kepada semua pihak yang telah membantu terselesaikannya artikel ilmiah ini dengan baik.

\section{Referensi}

Hasibuan, M. S. P. (2016). Manajemen Sumber Daya Manusia (Revition). Jakarta: PT Bumi Aksara.

Kartono, K. (2008). Pemimpin dan Kepemimpinan. Jakarta: PT. Raja Grafindo Persada.

Lusri, L., \& Siagian, H. (2017). Pengaruh Motivasi Kerja Terhadap Kinerja Karyawan Melalui Kepuasan Kerja Sebagai Variabel Mediasi Pada Karyawan Pt . Borwita Citra Prima Surabaya. Agora, 5(1), 1-8.

Robescu, O., \& Iancu, A.-G. (2016). The Effects of Motivation on Employees Performance in Organizations. Valahian Journal of Economic Studies, 7(2), 49-56. https://doi.org/10.1515/vjes-20160006

Sucipto. (2007). Penilaian Kinerja Keuangan. In USU Library.

Usmany, T. P., Hamid, D., \& Utami, H. N. (2016). Pengaruh Budaya Organisasi terhadap Komitmen Organisasi dan Kinerja Karyawan (Studi pada Karyawan Pabrik Gondorukem dan Terpentin Sukun Perum Perhutani Kesatuan Bisnis Mandiri Industri Gondorukem dan Terpentin II, Ponorogo). Jurnal Administrasi Bisnis S1 Universitas Brawijaya, 37(2), 38-44.

Zainal, V. R., \& Mulyadi. (2010). Kepemimpinan dan Perilaku Organisasi. Jakarta: PT. Raja Grafindo Persada. 